\title{
Fire risk in Austrian pine (Pinus nigra) plantations under various temperature and wind conditions
}

\author{
IMRe CSERESNYÉS*, ORSOLYA SZÉCSy, PÉTER CSONTOS \\ Research Institute for Soil Science and Agricultural Chemistry of the Hungarian \\ Academy of Sciences, Herman O. út 15, H-1022 Budapest, Hungary.
}

\begin{abstract}
The Austrian pine (Pinus nigra), an introduced conifer in Hungary, forms a highly flammable vegetation type. The fire risk of such stands was examined using McArthur's empirical forest fire danger model. Our study focused on the effects of temperature and wind speed on fire behaviour. By keeping the input parameters of the model constant while changing temperature and wind speed within a specified interval the resulting fire danger index (FDI) and fire behaviour were examined. The applied fixed parameters were: $30{ }^{\circ} \mathrm{C}$ temperature, $30 \%$ relative humidity, $30 \mathrm{~km} \mathrm{~h}^{-1}$ wind speed, 30 degree of slope and drought factor value 10. The annual trends of the Byram-Keetch drought index (BKDI) and the drought factor were also calculated. Our results show that increasing temperature and wind speed raises the FDI, flame height, rate of fire spread (ROS) and spotting distance. The amount of fuel does not influence the FDI, but increasing the amount promotes the ROS and raises the flame height. Wind speed was the most important factor in the ROS. A serious fire risk of these plantations was determined. The reliability of McArthur's model was proved by comparison of our results with experimental laboratory data based on literature.
\end{abstract}

Key words: drought factor, fire danger index, flame height, McArthur's model, Pinus nigra, rate of spread, plantation, wind

Abbreviations: BKDI - Byram-Keetch drought index, FDI - fire danger index, ROS rate of fire spread

\section{Introduction}

In Hungary, Austrian pine (Pinus nigra Arn.) plantations were first established for soil preservation and landscape protection purposes. The species was also used in afforestation in the Mediterranean areas of Europe to prevent soil erosion (BARČIĆ et al. 2006, ToPIĆ et al. 2008). In Hungary, the primary goal of the afforestation shifted towards wood production. Today, this alien species is responsible for some serious nature conservation problems. Owing to the accumulated litter fuels and strong shading by the pine canopy, the botani-

* Corresponding author, e-mail: cseresnyes.imre@rissac.hu

Copyright $^{\circledR} 2011$ by Acta Botanica Croatica, the Faculty of Science, University of Zagreb. All rights reserved. 
cally valuable floras of dolomite and limestone rock grasslands have been extensively impoverished or made locally extinct (CSONTOS et al. 1996, TAMÁs 2003, CSERESNYÉs et al. 2006). Consequently, monodominant Pinus nigra stands are occupying habitats that were previously occupied by native grasslands.

However, the most serious damage is caused by repeated forest fire events. That the frequency of forest fires has been increasing in recent decades was demonstrated world-wide (Niklasson and Granström 2000, Hartley 2002, PALIK et al. 2002, MuZy et al. 2008). This trend in increasing forest fires can be traced to human negligence or intentional burning (JoHNSON and LARSEN 1991, GRANSTRÖM 1993, ViegAS et al. 1999, BuRrows 2008). The risk of fire initiation in a forest depends not only on current meteorological and topographical factors, but also on the amount of accumulated flammable vegetation (MILLÁN et al. 1998, VIEGAS 1998). As a consequence of its slow decomposition, needle litter tends to accumulate in large quantities under Austrian pine stands (CSERESNYÉs et al. 2006, Csontos et al. 2007, KüÇÜK et al. 2007). For these reasons exotic pine plantations of Hungary may be more vulnerable to damaging fires than grasslands (which once occupied these sites) and the native broad-leaved forests of the country.

The dryness of the litter and the vegetation has a considerable influence on the scale of fire risk, such that the frequency and scale of forest fires increase during dry years (VIEGAS et al. 1990, 1992, GRANSTRÖM 1993, SwETNAM 1993).

With the application of an adequate fire danger model the potential degree of fire risk of the Hungarian Pinus nigra plantations was studied. We also aimed to determine the effects of air temperature and wind speed on the characteristics of fire.

\section{Materials and methods}

Hungary is situated in the warm temperate zone, which is ranked third among climatic regions regarding fire risk, after the Mediterranean and the wet subtropical areas. In Hungary, the yearly average of forest area damaged by fire ranges between 600 ha and 800 ha, but in extremely dry years the burnt area may exceed 2000 ha (ZAMBó 1995). Modelling objects were Austrian pine forests planted on dolomite hills of Pilis and Budai Mountains. Data on accurate localities and age of the stands (which ranged from 21 to 108 years) were known from local forest inventories. Each stand was larger (considerably larger in most cases) than 5 ha.

Fire danger modelling was carried out by applying McArthur's empirical model (NoBLE et al. 1980). This model was developed in Australia, but later it was successfully used under different climatic and fuel conditions in North America and Europe (PASTOR et al. 2003, SNYDER et al. 2006). The model requires the following input data for the prediction of fire risk and fire behaviour: air temperature, relative humidity, wind speed, slope degree, amount of fuel and drought factor. Determination of the actual value of drought factor was based on the amount of last precipitation, the number of days since last rain and the Byram-Keetch Drought Index (BKDI). Given this knowledge, the fire danger index (FDI), flame height, rate of spread (ROS) and spotting distance can be calculated by Forest Fire Danger Calculator software (Fig. 1).

Fire danger index means the probability of combustion, which has the following classes: 0-4: low; 5-11: middle; 12-23: high; 24-49: very high; above 50: extreme. BKDI 


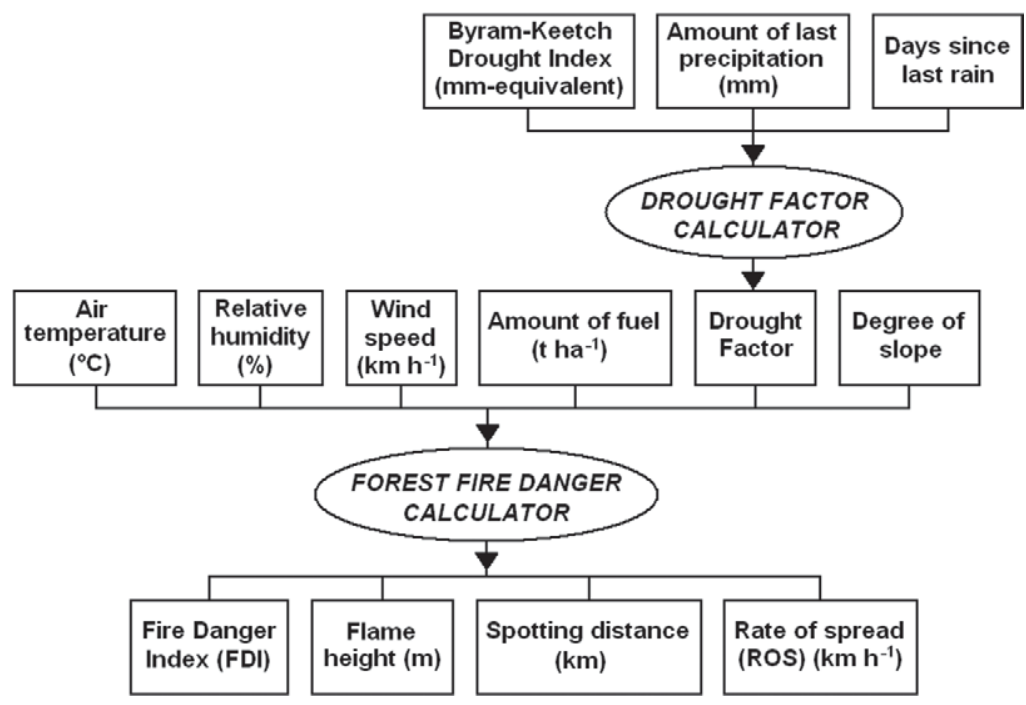

Fig. 1. Schematic diagram of McArthur's Forest Fire Danger model.

is an index characterizing the cumulative moisture deficiency in the $200 \mathrm{~mm}$ stratum of litter and upper soil layer expressed in mm-equivalent (KEETCH and BYRAM 1968). It also indicates water deficit in living plants and hence their flammability (XANTHOPOULOS et al. 2006). Daily BKDI has been calculated from 1985 to 2009 using daily maximum temperature and rainfall data from the Budapest-Lörinc meteorological station (N 47 $25^{\prime} 45^{\prime \prime}$; E 19¹0'56"; 138 m a.s.1.). By employing Drought Factor Calculator software, daily drought factor values were calculated for the 1985-2009 period. These daily drought factors were averaged for every ten days, then the average of the 25 years was illustrated together with the wettest and the driest years.

To study the effect of changing temperature or wind speed on fire-risk relations, one of these two factors was changed within a specified interval (leaving the other five input parameters constant) and the resulting four outputs of the model (see Fig. 1) were examined.

The following constant values and intervals of change were used:

1) Temperature: Its fixed value was $30{ }^{\circ} \mathrm{C}$. This temperature is common in summer (KAKAS 1960). When temperature was the selected variable parameter, its value was changed from 0 to $40{ }^{\circ} \mathrm{C}$. The daily maximum temperature of $40^{\circ} \mathrm{C}$ is rare but not negligible, since there were 10 consecutive days above $40{ }^{\circ} \mathrm{C}$ in Hungary in the year 2008 .

2) Relative humidity: $30 \%$. Similar or lower air humidity values occur frequently in Hungary between July and September (BACsó et al. 1953).

3) Wind speed: $30 \mathrm{~km} \mathrm{~h}^{-1}$ (gale force 5 in the Beaufort-Köppen scale). Such strong winds are frequent in each season of the year. Intervals of the step-wise testing ranged between 0 and $70 \mathrm{~km} \mathrm{~h}^{-1}$. The windiest months are June and July in Hungary (BACsó et al. 1953). Commonly, the highest wind speeds are usually recorded between 12 p. m. and 3 p. m., though they can vary to a great extent depending on the local weather conditions. Steep slopes and sharp ridges are typical of dolomite hills, thus when examining these areas we have to reckon with strong or stormy squalls even on relatively calm days. 
4) Degree of slope: $30^{\circ}$. This value is typical of dolomite hills. Besides enhancing the flame height, increase in the degree of slope is also often a driving factor for crown fire initiations (SANTONI and BALBI 1998). Dolomite areas abound in steep slopes, consequently this topographical effect contributes significantly to fire risk conditions.

5) Amount of fuel: According to McArthur's model the fire behaviour depends on the amount of litter only with a diameter of less than $6 \mathrm{~mm}$ (NOBLE et al. 1980). From previous studies in Austrian pine plantations, the litter fuel less than $6 \mathrm{~mm}$ is $10,574 \mathrm{~kg} \mathrm{ha}^{-1}$ in the age class of 20-35 years, $14,024 \mathrm{~kg} \mathrm{ha}^{-1}$ in the age class of 35-60 years, 18,564 $\mathrm{kg} \mathrm{ha}^{-1}$ in the age class of $60-80$ years and $13,056 \mathrm{~kg} \mathrm{ha}^{-1}$ in stands above 80 years (CSERESNYÉs et al. 2006). Since the amount of fuel reaches a maximum mass in the 60-80 year stand age class, forest fires are expected to be most severe in this age class. For the purpose of this study, the stand age class above 80 years was ignored, firstly because such old monodominant Austrian pine forests are relatively rare and secondly, because according to our former statistical analysis, the amount of accumulated fuel in this age class corresponds essentially to the fuel load in the stand age of 35-60 years. Although the probability of combustion (namely the FDI) is independent of the amount of fuel, higher amounts of litter fuel increase the flame height, the ROS and the spotting distance. Some experiments of MoRVAN and DUPUY (2001) verified linear rate connection between the ROS and the fuel mass until about $20,000 \mathrm{~kg} \mathrm{ha}^{-1}$, as above that value they became independent of each other.

6) Drought factor: This indicates the dryness of vegetation, litter and upper soil layer. Its value is an integer number between 1 and 10. Based on our previous investigations (CSERESNYÉS and CSONTOS 2006), we chose the highest figure (10) as the constant value. Detailed analyses proved that periods characterized by the highest drought conditions can prevail not only in extreme dry years but also in years with average weather conditions. Only the length and frequency of drought periods are of importance.

\section{Results}

Based on BKDI values and daily amounts of rainfall the annual drought factor trend was calculated. Drought factor changes are evident in the period 1985 to 2009, in the wettest and the driest years, as well as in the 25 year average (Fig. 2). From January to June the 25 year mean value of the drought factor was about five. In June it began to increase, reaching its maximum (above value 7) between the middle of August and September. Until the end of November it was decreasing continuously, when it stabilized around value five. Thus, August and September are generally the driest months of the year. In the driest year (2000) the drought factor reached the highest possible value (10), maintaining this for four ten-day periods. In 2000, the extreme arid conditions lasted 99 days, from $15^{\text {th }}$ June to $4^{\text {th }}$ November. The longest unbroken period, when the drought factor was at value 10, was continuously observed for 29 days (between $7^{\text {th }}$ October and $4^{\text {th }}$ November).

FDI is influenced by temperature and wind speed (Figs. 3a, b). FDI is independent of the amount of fuel, thus also of the stand age, age classes being not distinguished. FDI increased by the rising air temperature (Fig. 3a). FDI was claimed to be $»$ high $«$ at $10{ }^{\circ} \mathrm{C}$ temperature and »very high « at $30^{\circ} \mathrm{C}$. Increasing wind speed causes an exponential increase in the FDI (Fig. 3b). Under the chosen constant parameters the fire risk is »high « even if the weather is entirely calm, but at a wind speed of $60 \mathrm{~km} \mathrm{~h}^{-1}$ FDI becomes »extreme«. 


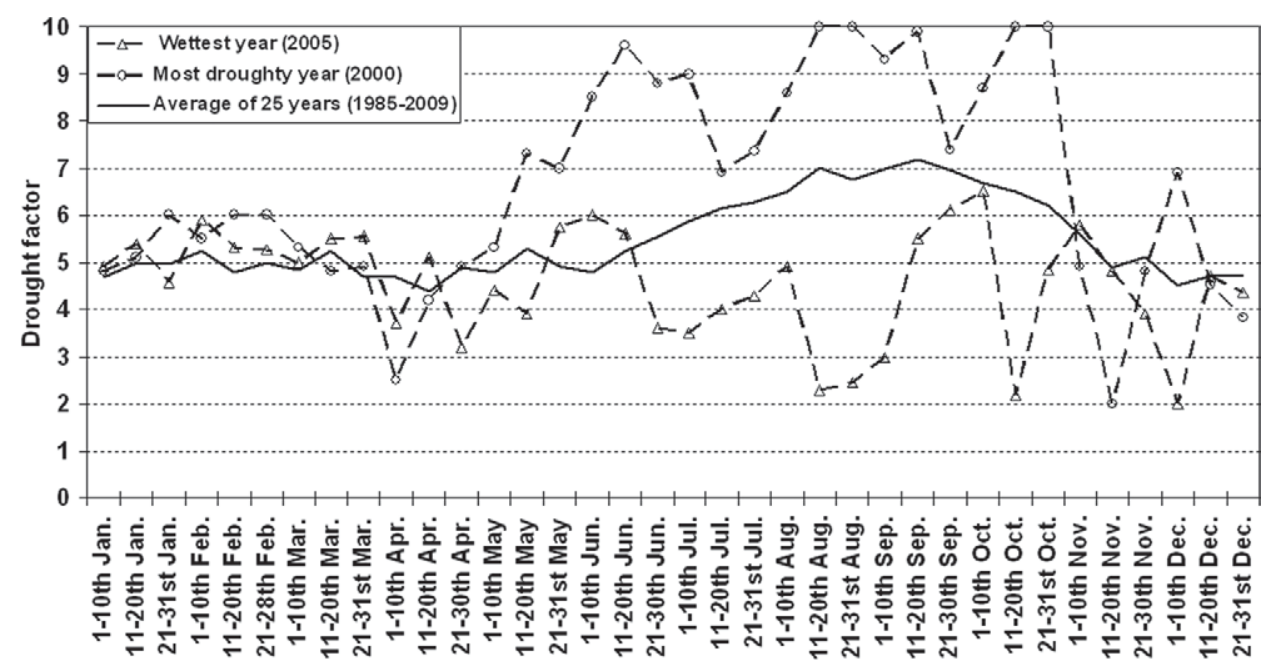

Period

Fig. 2. Annual changes of the mean value of the drought factor as the average of years between 1985 and 2009, as well as in the wettest year (2005) and in the driest year (2000) of that period.

Flame height was not only increased by air temperature (Fig. 3c) and wind speed (Fig. $3 \mathrm{~d})$, but also by the amount of fuel. Therefore the lowest flame height was observable in the stand age class 20-35 years, while the highest flame height was predicted in the age class of $60-80$ years. Expected flame heights are $4.22 \mathrm{~m}$ in stand age class $20-35$ years, $6.70 \mathrm{~m}$ in the age class of 35-60 years and $9.19 \mathrm{~m}$ in the age class of 60-80 years. In the stand age class of 60-80 years, in case of a $70 \mathrm{~km} \mathrm{~h}^{-1}$ wind speed, flame height approximates to $20 \mathrm{~m}$, but even in the youngest stands it exceeds $10 \mathrm{~m}$.

Spotting distance also rose with the amount of fuel. Consequently, we have to expect the minimum spotting distance in the youngest stands, while the highest values are observable in the age class of 60-80 years. Spotting distance was also enhanced by air temperature (Fig. 3e), and its value may be notable even at relatively low temperature. In the stand age class $60-80$ years it can exceed $1.5 \mathrm{~km}$ if temperature reaches $30^{\circ} \mathrm{C}$. Spotting distance was principally influenced by wind speed (Fig. 3f). In the highly inflammable stand age class the spotting distance is nearly $0.6 \mathrm{~km}$ in calm weather, but a squall with $70 \mathrm{~km} \mathrm{~h}^{-1}$ wind speed can transport the glowing embers to a distance of $4.5 \mathrm{~km}$.

Rate of fire spread (ROS), like flame height and spotting distance, increases with the amount of fuel. The ROS is much larger upslope than downslope or on flat terrain. On a 30 degree slope, the ROS of an ascending fire is eight fold higher than that of a descending fire. Our result graphs (Fig. $3 \mathrm{~g}$ and $3 \mathrm{~h}$ ) show only the upslope spreading rates. A rising temperature increases the ROS (Fig. 3g). In stand age class 60-80 years the predicted ROS can approach $5 \mathrm{~km} \mathrm{~h}^{-1}$ on a hot summer day, when the temperature reaches $35^{\circ} \mathrm{C}$. Naturally, the first factor enhancing the ROS is wind speed (Fig. 3h). Based on our described constant parameters the ROS is $4.19 \mathrm{~km} \mathrm{~h}^{-1}$ upslope in the age class of 60-80 years. The ROS of a descending fire does not exceed $1.35 \mathrm{~km} \mathrm{~h}^{-1}$ at any of the used parameter combination. 


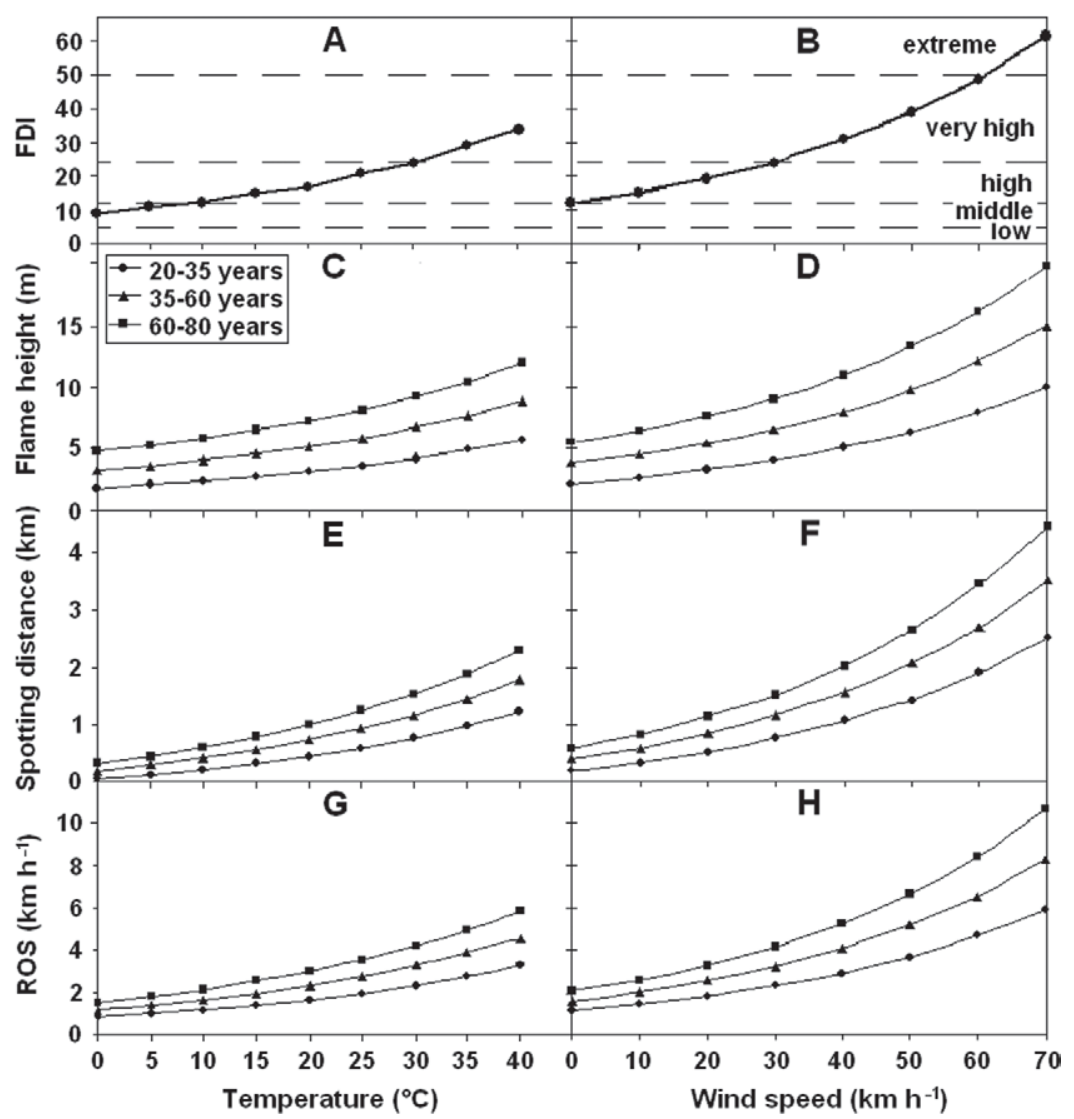

Fig. 3. Changes of the Fire Danger Index (FDI), flame height, spotting distance and rate of fire spread (ROS) with the temperature and wind speed in Pinus nigra stands. (Since the FDI is independent of the amount of fuel, age classes are not distinguished in Fig. 3a and 3b.)

\section{Discussion}

The drought factor trend clearly shows that August and September are the most crucial months from the point of view of fire events. We obtained similar results during the calculation of BKDI in a former study (CSERESNYÉS and CsONTOS 2006). SNYDER et al. (2006) also demonstrated the close connection between BKDI and drought factor values. The importance of these two drought indicators is proved by one of the most serious forest fires of Budai Mountains, which devastated more than 100 ha of pine stand on $15^{\text {th }}$ August 1993, near village Nagykovácsi, $15 \mathrm{~km}$ west from Budapest. On this day the calculated BKDI was rather high, $80.25 \mathrm{~mm}$-equivalent, and the drought factor reached value 9 (CSERESNYÉS and CsONTOS 2006). These data precisely show the drought conditions prevailing in the mentioned day, and furthermore the daily maximum temperature was $33{ }^{\circ} \mathrm{C}$, thus further increasing the fire risk.

The fire danger index as well as fire behaviour are both affected by air temperature and wind speed. In general, wind speed has a stronger influence on fire risk than temperature. 
FDI can reach the »extreme« class only in strong winds, and the flame height also rises more vigorously with wind speed (increasing the probability of crown fires). Spotting distance is also principally influenced by wind conditions; therefore windy weather makes fire fighting considerably difficult by forming local fire-seats far away from the main fire front. A large ROS also contributes to this problem. In the highly inflammable stand age class (60-80 years) the ROS is more than $5 \mathrm{~km} \mathrm{~h}^{-1}$ with a $40 \mathrm{~km} \mathrm{~h}^{-1}$ wind speed, but at $70 \mathrm{~km} \mathrm{~h}^{-1}$ wind speed it exceeds $10 \mathrm{~km} \mathrm{~h}^{-1}$. Experimental field works in Turkish Pinus nigra stands and shrublands, provided evidence that wind speed, air temperature and the moisture content of litter, greatly contributed to ROS (KüçüK et al. 2007, 2008b; BILGILI and SAGLAM 2003). Moreover, the amount of flammable biomass has considerable importance in respect of fire behaviour and fire management (KüÇÜK et al. 2008a, SAGLAM et al. 2008), thus in Hungary the $60-80$ years stand age class of Austrian pine plantations is the most vulnerable to devastating fires.

In order to test the correspondence between the results of our study and reality, we compared the outputs of the model with experimental laboratory results known from the scientific literature.

On an experimental basis, VIEGAS (1998) proved that a fire front propagating upslope has a rate of advance much greater than on horizontal terrain, and its value increases with terrain inclination. The ROS of a descending fire is very similar to that on a flat terrain and besides, it is independent of terrain inclination. If the degree of slope reaches 30 , the measurable ROS will be 4-6 fold higher than on flat ground (VIEGAS et al. 1994), so this difference is smaller than predicted by McArthur's model. In accordance with MoRANDINI et al. (2001), on a 30 degree slope an ascending fire has an 8-10 fold higher ROS than a fire on horizontal terrain. Their experiments were carried out in the laboratory, by burning a Pinus pinaster Aiton fuel bed. The 7.8-8 fold higher difference between upslope and downslope ROS predicted by McArthur's model is practically equivalent to these laboratory results. In other experimental circumstances less (5-7 fold higher) difference was observed between the upslope and downslope ROS, but the variances depended on the moisture content of the litter (SANTONI and BALBi 1998, GonZALEZ et al. 2008).

Influence of wind speed on the ROS was examined under similar conditions (SIMEONI et al. 2001). ROS showed more increase with wind speed than predicted by McArthur's model; consequently this model might underestimate the effect of wind speed on the ROS. MORVAN and DuPUY (2001) measured ROS with changes to the amount of fuel. In the present study, when the fuel mass was changed from $10,574 \mathrm{~kg} \mathrm{ha}^{-1}$ (stand age class 20-35 years) to $18,564 \mathrm{~kg} \mathrm{ha}^{-1}$ (stand age class $60-80$ years), an increase of about $75 \%$, it caused a 1.8 fold higher ROS. MORVAN and DUPUY (2001) noticed only 1.5-1.6 fold higher differences by using of similar range of fuel quantity, whereas GLITZENSTEIN et al. (2006) observed much larger (2.1-2.5 fold) differences among spreading rates. These examples imply that McArthur's model properly estimates the influence of fuel mass on ROS.

Summarizing these comparative results, we can conclude that the outputs of McArthur's model generally correspond to the experimental data, but in some cases they differ to a certain degree. More detailed comparison with literature data was not possible, because in many publications relative humidity, air temperature and in some cases even the moisture content and the amount of fuel were not described. 
The results of our studies show considerable fire risk in the Austrian pine stands of Hungary, more or less similar to that of Mediterranean areas. Consequently we have to pay more attention to these plantations not only during dry and warm, but also during windy periods of the year to prevent forest fires and to avoid serious natural and economic losses.

\section{Acknowledgements}

The authors thank Erika Bózsing for helping with the field-work and foresters Gábor Bakon, István Apatóczky and Viktor Farkas for supplying data concerning Austrian pine stands. We are grateful to the reviewers for their useful comments and for language copy editing. This research was supported by the Hungarian National Science Foundation (OTKA T037732).

\section{References}

BACsó, N., KAKAS, J., TAKÁCs, L., 1953: Climate of Hungary (In Hungarian). Országos Meteorológiai Intézet, Budapest.

BARČIĆ, D., HRŠAK, V., ŠPANJOL, Ž., 2006: The ameliorative effects of pine cultures on forest sites on the island of Rab in southwest Croatia. Forest Ecology and Management 237, 39-46.

BilgiLi, E., Saglam, B., 2003: Fire behavior in maquis fuels in Turkey. Forest Ecology and Management 184, 201-207.

Burrows, N. D., 2008: Linking fire ecology and fire management in south-west Australian forest landscapes. Forest Ecology and Management 255, 2394-2406.

CSERESnYÉs, I., CsOntos, P., 2006: Change in drought conditions of Pinus nigra stands in Hungary (In Hungarian). Tájökológiai Lapok, 255-268.

CSERESnYÉs, I., Csontos, P., BózsIng, E., 2006: Stand age influence on litter mass of Pinus nigra plantations on dolomite hills in Hungary. Canadian Journal of Botany 84, 363-370.

Csontos, P., Horánszky, A., Kalapos, T., Lokös, L., 1996: Seed bank of Pinus nigra plantations in dolomite rock grassland habitats, and its implications for restoring grassland vegetation. Annales Historico-naturales Musei Nationalis Hungarici 88, 69-77.

Csontos, P., Rocchini, D., BACARO, G., 2007: Modelling factors affecting litter mass components of pine stands. Community Ecology 8, 247-255.

Glitzenstein, J. S., Streng, D. R., Achtemeier, G. L., NAeher, L. P., Wade, D. D., 2006: Fuels and fire behaviour in chipped and unchipped plots: Implications for land management near the wildland/urban interface. Forest Ecology and Management 236, 18-29.

Gonzalez, J. R., Del Barrio, G., Duguy, B., 2008: Assessing functional landscape connectivity for disturbance propagation on regional scales - A cost-surface model approach applied to surface fire spread. Ecological Modeling 211, 121-141.

Granström, A., 1993: Spatial and temporal variation in lightning ignitions in Sweden. Journal of Vegetation Science 4, 737-744.

HARTLEY, M. J., 2002: Rationale and methods for conserving biodiversity in plantation forest. Forest Ecology and Management 155, 81-95. 
Johnson, E. A., LARSEn, C. P. S., 1991: Climatically induced change in fire frequency in the southern Rockies. Ecology 72, 194-201.

KAKAS, J., 1960 (ed.): Climatic atlas of Hungary (In Hungarian). Akadémiai Kiadó, Budapest.

KeEtch, J. J., ByRAM, G. M., 1968: A drought index for forest fire control. U.S.D.A. Forest Service Research Paper SE-38. Southeastern Forest Experiment Station, Asheville, NC.

KüÇÜK, Ö., BILGILI, E., BAYSAL, I., 2007: Fire development from a point source in surface fuels of a mature anatolian black pine stand. Turkish Journal of Agriculture and Forestry $31,263-273$.

KüÇÜK, Ö., BILGILI, E., SAGlam, B., 2008a: Estimating crown fuel loading for calabrian pine and Anatolian black pine. International Journal of Wildland Fire 17, 147-154.

KüÇÜK, Ö., BIlgili, E., SAglam, B., BASKAYA, S., Dinç DuRmaz, B., 2008b: Some parameters affecting fire behavior in Anatolian black pine slash. Turkish Journal of Agriculture and Forestry 32, 121-129.

Millán, M. M., Estrela, M. J., Badenas, C., 1998: Synoptic analysis of meteorological processes relevant to forest fire dynamics on the Spanish Mediterranean coast. In: MORENO, J. M. (ed.), Large forest fires, 1-30. Backhuys Publishers, Leiden.

Morandini, F., SANTONI, P. A., BALBI, J. H., 2001: The contribution of radiant heat transfer to laboratory-scale fire spread under the influences of wind and slope. Fire Safety Journal 36, 519-543.

Morvan, D., DupuY, J. L., 2001: Modelling of fire spread through a forest fuel bed using a multiphase formulation. Combustion and Flame 127, 1981-1994.

Muzy, A., Nutaro, J. J., Zeigler, B. P., Coquillard, P., 2008: Modeling and simulation of fire spreadig through the activity tracking paradigm. Ecological Modelling 219, 212225.

Niklasson, M., GrAnströM, A., 2000: Numbers and sizes of fires: long-term spatially explicit fire history in a Swedish boreal landscape. Ecology 81, 1484-1499.

Noble, I. R., BARy, G. A. V., Gill, A. M., 1980: McArthur's fire-danger meters expressed as equations. Australian Journal of Ecology 5, 201-203.

PAlik, B. J., Mitchell, R. J., Hiers, J. K., 2002: Modelling silviculture after natural disturbance to sustain biodiversity in the Longleaf pine (Pinus palustris) ecosystem: balancing complexity and implementation. Forest Ecology and Management 155, 347-356.

Pastor, E., ZÁrate, L., Planas, E., Arnaldos, J., 2003: Mathematical models and calculation system for the study of wildland fire behaviour. Progress in Energy and Combustion Science 29, 139-153.

Saglam, B., KüÇÜK, Ö., Bilgili, E., Dinç Durmaz, B., BAysal, I., 2008: Estimating fuel biomass of some shrub species (maquis) in Turkey. Turkish Journal of Agriculture and Forestry 32, 349-356.

SANTONi, P. A., BALBI, J. H., 1998: Modelling of two-dimensional flame spread across a sloping fuel bed. Fire Safety Journal 31, 201-225. 
Simeoni, A., SAntoni, P. A., Larini, M., Balbi, J. H., 2001: On the wind advection influence on the fire spread across a fuel bed: modelling by a semi-physical approach and testing with experiments. Fire Safety Journal 36, 491-513.

Snyder, R. L., Spano, D., Duce, P., Baldocchi, D., Xu, L., Paw, U. K. T., 2006: A fuel dryness index for grassland fire-danger assessment. Agricultural and Forest Meteorology $139,1-11$.

Swetnam, T. W., 1993: Fire history and climate change in giant sequoia groves. Science $262,885-889$.

TAMÁs, J., 2003: The history of Austrian pine plantations in Hungary. Acta Botanica Croatica 62, 147-158.

Topić, V., Anić, I., Butorac, L., 2008: Effects of stands of black pine (Pinus nigra Arn.) and Aleppo pine (Pinus halepensis Mill.) on the protection of soil from erosion. Ekológia Bratislava 27, 287-299.

Xanthopoulos, G., Maheras, G., Gouma, V., Gouvas, M., 2006: Is the Keetch-Byram drought index (KBDI) directly related to plant water stress? Forest Ecology and Management 234 (Supplement), 27.

VIEGAS, D. X., 1998: Weather, fuel status and fire occurrence: predicting large fires. In: Moreno, J. M. (ed.), Large forest fires, 31-48. Backhuys Publishers, Leiden.

Viegas, D. X., Bovio, G., Ferreira, A. D., Nosenzo, A., Sol, B., 1999: Comparative study of various methods of fire danger evaluation in Southern Europe. International Journal of Wildland Fire 9, 235-246.

Viegas, D. X., Varela, V. G. M., Borges, C. P., 1994: On the evolution of a linear fire front in a slope. Proceedings 2 International Conference on Forest Fire Research, Coimbra, Portugal, 301-318.

Viegas, D. X., Viegas, M. T., Ferreira, A. D., 1990: Characteristics of some forest fuels and their relation to the occurence of fires. Proceedings 1 International Conference on Forest Fire Research, Coimbra, Portugal, 13.

Viegas, D. X., Viegas, M. T., Ferreira, A. D., 1992: Moisture content of fine forest fuels and fire occurence in Central Portugal. International Journal of Wildland Fire 2, 69-86.

ZAMBÓ, P., 1995: Forest fires in years 1993 and 1994 on the territory of Pilis Forest Inventory, degree of losses and efforts for restoration (In Hungarian). Erdészeti Lapok 130, 152. 